\title{
Coronary angiographic findings among diabetic and non-diabetic patients
}

\author{
Dhiyaa A. Alhamadani, Fakher Y. Husain, Mahmood A. Abbo \\ Department of Medicine, College of Medicine, University of Mosul.
}

(Ann. Coll. Med. Mosul 2009; 35(1): 65-72).

Received: $26^{\text {th }}$ Oct 2008; Accepted: $12^{\text {th }}$ Jul 2009.

\begin{abstract}
objectives: Atherosclerotic coronary artery disease (CAD) is a major cause of death all over the world. Among patients with CAD there are many of them having diabetes mellitus which is regarded as a major additive risk factor. Diabetic patients who developed CAD carry high morbidity and mortality rates.

The objective of this study was to analyze the coronary angiographic outcome of patients with type two diabetes mellitus suspected to have coronary artery disease and comparing these results with non-diabetic patients.
\end{abstract}

Methods: Patients referred to Mosul Cardiac Catheterization Unit of Ibn-Sena Teaching Hospital for coronary angiography were serially included until obtaining a total of 75 diabetic and 75 non-diabetic patients with predicted coronary artery disease and with different ischemic heart disease risk factors including obesity, smoking, hypertension and dyslipidemia. All of them underwent coronary angiography.

Result: Diabetic patients showed more significant stenotic lesions. Moreover the lesions in the coronary artery were more diffuse with higher incidence of multivessel involvement in comparison to non-diabetic patients. Also diabetic patients show increasing incidence of the left main stem artery involvement which carry very high mortality rate.

Conclusion: Diabetes mellitus is an independent risk factor for coronary artery disease associated with more advanced, serious and extensive obstructive atherosclerotic lesions in the coronary arteries.

مقـدمة: تصلب الثر ايين التاجية العصادية هو أحد أكثر أسباب الوفاة انتشارا في العالم. ويعتبر السكري عامل خطورة

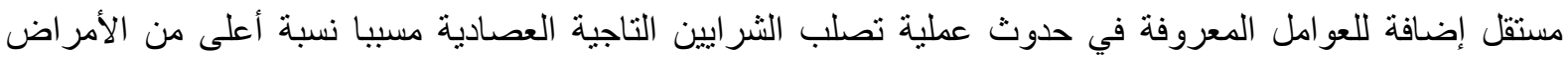
و الوفاة و التي ممكن أن تكون بسبب طبيعة التغير ات العصادية للثر ايين التاجية المنتشرة و الثثديدة في داء السكر.

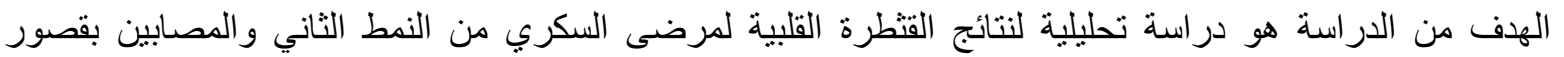

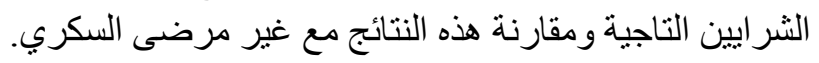
طريقة البحث: شملت هذه الدراسة التحليلية المستقلية (10 (10) مريض أجريت لهم عملية قتطرة تشخيصية للثر ايين القلبية

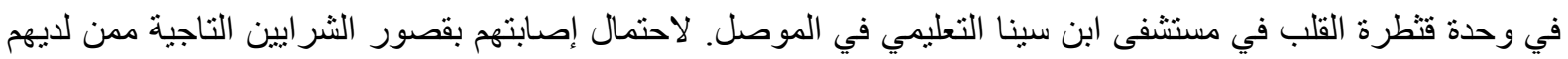
عو امل خطورة متعددة مثل السمنة والتدخين و الضغط و اختلال دهون الدم ونم تقسيم المرضى إلى مجمو عتين بالاعتماد على وجود السكري أو عدمه. النتأسـج: أظهرت الدراسة بأن السكري يعمل على تضييق الثرايين بشكل ملحوظ وتبين أن قصور الثرايين التاجية منتشر أكثر و أثند في مرضى السكر. 


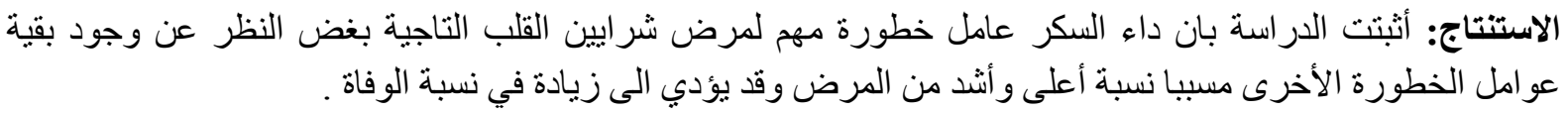

D iabetes mellitus is a chronic disease with approximately 150 million people worldwide are suffering from this condition and the number is expected to rise to 300 million by $2025^{(1)}$. With the increasing prevalence, diabetes is rapidly growing into a global public health problem. For many years, cardiovascular diseases and especially coronary heart disease (CHD) have been the main cause of premature death in many countries. In addition to the other classical risk factors (age, male sex, smoking, hypertension and hypercholesterolemia, etc.), diabetes is recognized as an important risk factor for cardiovascular disease $^{(2)}$. A previous study ${ }^{(3)}$ showed that patients with diabetes mellitus are at an increased risk for the development of coronary artery disease. The cardiovascular disease is a major consequence of this chronic condition and is regarded as the leading cause of death in type two diabetes mellitus (T2DM), $(4,5,6)$. Although there has been considerable improvement in managing patients with coronary artery disease, unfavorable events remained heightened among patients with diabetes; in other words, diabetes independently worsens long-term prognosis for medically treated patients ${ }^{(7,8)}$. Epidemiological data from the Framingham Study demonstrated a two- to fourfold increase in atherosclerotic disease in diabetic patients and the risk of death from cardiovascular disease is much higher for patients with diabetes compared with those without diabetes ${ }^{(9)}$. Also diabetic patients who have had myocardial infarction have a higher mortality rate in the acute phase of myocardial infarction and in long-term follow-up even when they were treated with fibrinolytic regimen. ${ }^{(10-12)}$

The aim of this work is to study the impact of diabetes mellitus on coronary arteries (the characters of coronary artery lesion and its extent), and comparing the angiographic findings between diabetic and non diabetic patients.

\section{Patients and methods}

Patients referred to Mosul Cardiac Catheterization Unit of Ibn-Sena Teaching Hospital for coronary angiography were serially included until obtaining a total of 75 diabetic and 75 non-diabetic patients between February 2007 and August 2007. All of them predicted to have coronary artery disease and with different ischemic heart disease risk factors including obesity, smoking, hypertension and dyslipidemia. All of them underwent coronary angiography. Written informed consent was obtained from all patients before the study. Some patients had previously known clinical evidence of $\mathrm{CHD}$ confirmed by typical history of disease and by the presence of classical electrocardiographic ischemic changes; not all of them have positive exercise electrocardiographic test.

The diabetic patients were classified as having diabetes if it was documented on their medical reports, if they were taking insulin or oral hypoglycemic agents, or on the basis of the national Diabetes Data Group and WHO criteria for diagnosis of DM

* Symptom of DM plus RBS > $11.1 \mathrm{mmol} / \mathrm{L}$ (200 mg /dL) or

* FBS $>7.0 \mathrm{mmol} / \mathrm{L}(126 \mathrm{mg} / \mathrm{dL})$ or

* Two -hour plasma glucose > $11.1 \mathrm{mmol} / \mathrm{L}$ $(200 \mathrm{mg} / \mathrm{dL})$ during an $\mathrm{OGGT}^{(13)}$. The nondiabetic patients were considered as the control group. Preliminary evaluation of all patients included the clinical characteristics of the patients, age, sex, duration of CHD, history of myocardial infarction, history of hypertension and/or if the measured systolic blood pressure was $\geq 140 \mathrm{mmHg}$ and/or diastolic blood pressure $\geq 90 \mathrm{mmHg}$ at day of admission with the presence or absence of the evidence of target organ involvement, smoking, (current or prior). Dyslipidemia was considered as a risk factor if the patient has any one of the following abnormalities: total cholesterol $>5.17 \mathrm{mmol} / \mathrm{L}(200 \mathrm{mg} / \mathrm{dL})$, low density lipoprotein $>2.6 \mathrm{mmol} / \mathrm{L}(100 \mathrm{mg} / \mathrm{dL})$, high density lipoprotein men $<1.15 \mathrm{mmol} / \mathrm{L}(<$ 
$45 \mathrm{mg} / \mathrm{dL})$. Women $<1.4 \mathrm{mmol} / \mathrm{L}(<55$ $\mathrm{mg} / \mathrm{dL})$, and triglyceride $>1.7 \mathrm{mmol} / \mathrm{L}(>150$ $\mathrm{mg} / \mathrm{dL}) .{ }^{(16)}$

The criteria for the metabolic syndrome have been looked for in both groups ${ }^{(16)}$. As shown in Table (1). Coronary angiography was performed at the cardiac catheterization unit of (Ibn-Sena Teaching Hospital) using Siemens' *AXIOM Artis equipment (Germany).

We routinely perform angiography in at least four projections. These projections are recorded in our data base. Qualitative angiographic assessment regarding the presence or absence of significant coronary artery lesion was done by at least two expert interventional cardiologists during or immediately after the procedure. The angiogram was assessed for the presence or absence of significant vessel occlusion.

The degree of luminal narrowing was recorded in percentage of prestenotic diameter. Internal luminal narrowing of $70 \%$ was considered significant, except for the left main coronary artery, in which $50 \%$ stenosis was regarded as significant. Based on the results of coronary angiography, the character of the lesion was defined as diffuse by the presence of more than one significant lesion in the culprit artery or if the obstructed lesion was more than $20 \mathrm{~mm}$ in length ${ }^{(17)}$. Statistical analysis was performed using Student's $t$ test between two proportions and Chi square test.

Data are expressed as means \pm SD or $n(\%)$. $\mathrm{P} \leq 0.05$ was considered statistically significant.

Table (1): clinical identification of metabolic syndrome.

\begin{tabular}{|l|}
\hline $\begin{array}{l}\text { Central obesity: waist circumference }>102 \\
\mathrm{~cm}(\mathrm{M}),>88 \mathrm{~cm}(\mathrm{~F})\end{array}$ \\
\hline $\begin{array}{l}\mathrm{Hpertriglyceridemia:} \text { : Triglycerides }>1.7 \mathrm{~m} \\
\mathrm{~mol} / \mathrm{L}\end{array}$ \\
\hline $\begin{array}{l}\text { Low } \mathrm{HDL} \text { cholesterol: }<1.0 \mathrm{mmol} / \mathrm{L}(\mathrm{M}) \text {, and }< \\
1.3 \mathrm{~m} \mathrm{~mol} / \mathrm{L}(\mathrm{F})\end{array}$ \\
\hline $\begin{array}{l}\text { Hypertension: Blood pressure }>130 \mathrm{~mm} \mathrm{Hg} \\
\text { systolic or }>85 \mathrm{~mm} \text { Hg diastolic }\end{array}$ \\
\hline $\begin{array}{l}\text { Fasting plasma glucose }>6.0 \mathrm{~m} \mathrm{~mol} / \mathrm{L} \mathrm{or} \\
\text { previously diagnosed type } 2 \text { diabetes }\end{array}$ \\
\hline
\end{tabular}

Any three risk factors

\section{Results}

\section{Risk Factor Characteristic}

Baseline characteristics were comparable between the patients with T2DM and those without diabetes mellitus as shown in Table (2). The results of the analysis of the baseline clinical characteristics showed that patients with diabetes were older (mean age was $56.3_{ \pm}$ 7.4 years) than non-diabetic patients (mean age $53.9 \pm 8.8$ years). There was an equal proportion of men and women (48 men 64\%) and (27 women $36 \%)$ in both groups. The current smoking habit was more frequent in the diabetics $18(24 \%)$ than non-diabetics 10 $(13.3 \%) \quad(p=0.70)$. Patients with diabetes more often had arterial hypertension 44 $(58.7 \%)(p=0.05)$ with a higher incidence of previous attack of acute myocardial infarction $23(30.7 \%)$. The prevalence of obesity and metabolic syndrome were higher in diabetics group $(46.7 \%), \quad(p=0.002)$ when compaired with other group as shown in Tables (3) and (4).

There was no statistically significant differences in the atherogenic index (the ratio of TC to HDL lipoprotein cholesterol) between two groups as shown in Table (5). The mean duration of DM was $6.33 \pm 4.9 \mathrm{y}$. Most of diabetic patients seem to have poor control of their diabetes as the mean FBS for the studied group was $9.64 \pm 3.5$.

\section{Angiographic Characteristics}

Regarding the angiographic characteristics of the studied groups, the non-significant lesions on angiography were more commonly detected in non-diabetics compared with those with diabetes ( $42 \%$ versus $12.0 \%$ respectively) $(p<0.001)$. On the other hand, 19 diabetic patients (24\%) had a smaller vessel size and more diffuse lesion when compared with nondiabetic patients $(p=0.009)$. Multivessel disease $\{$ (two vessel disease $p=0.05$ ) and (three vessel disease $p<0.001$ ) $\}$ were also more frequently present in diabetic group than non-diabetic group, as shown in Tables $(6,7)$.

The left main stem lesion was seen more frequently in diabetic patients $(p<0.001)$ as shown in Table (8). 
Table (2): Clinical characteristics of diabetic and non-diabetic patients.

\begin{tabular}{|c|c|c|c|c|}
\hline \multicolumn{2}{|c|}{ Variables } & Diabetics $(n=75)$ & Non-diabetics $(n=75)$ & $p$-value \\
\hline \multirow{2}{*}{ Sex } & $\overline{\text { Male }}$ & $488(64.0 \%)$ & $488(64.0 \%)$ & \multirow{2}{*}{ NS } \\
\hline & Female & $27(36.0 \%)$ & $27(36.0 \%)$ & \\
\hline \multicolumn{2}{|c|}{ Mean age \pm SD $(y r)$} & $56.3 \pm 7.4$ & $53.99 \pm 8.8$ & NS \\
\hline \multicolumn{2}{|c|}{ Duration of DM (yr) } & $6.33 \pm 4.9$ & -- & -- \\
\hline \multicolumn{2}{|c|}{ Duration of IHD (yr) } & $3.2 \pm 3.67$ & $3.21 \pm 4.71$ & NS \\
\hline \multicolumn{2}{|c|}{ FBS (mmol/L) } & $9.64 \pm 3.5$ & $5.0 \pm 0.5$ & -- \\
\hline \multicolumn{2}{|l|}{ Prior MI } & $23(30.7 \%)$ & $16(21.3 \%)$ & NS \\
\hline \multicolumn{2}{|l|}{ HT } & $44(58.7 \%)$ & $32(42.7 \%)$ & 0.05 \\
\hline \multirow{2}{*}{ Smoking } & Current & $18(24.0 \%)$ & $16(21.3 \%)$ & NS \\
\hline & Prior & $10(13.3 \%)$ & 11(14.7) & NS \\
\hline
\end{tabular}

NS $=$ Not significant

Table (3): Obesity parameters of the studied groups.

\begin{tabular}{|c|c|c|c|c|c|}
\hline \multirow{2}{*}{ BMI } & \multicolumn{2}{|c|}{ Diabetes $(n=75)$} & \multicolumn{2}{|c|}{ Non-diabetes $(\mathrm{n}=75)$} & \multirow{2}{*}{$p$-value } \\
\hline & No. & $\%$ & No & $\%$ & \\
\hline < 25 (Normal) & 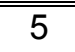 & $6.6 \%$ & 11 & $14.6 \%$ & 0.05 \\
\hline $25-30$ (over wt) & 26 & $34.6 \%$ & 25 & $33.4 \%$ & NS \\
\hline $30-35$ & 18 & $24.0 \%$ & 21 & $26.7 \%$ & NS \\
\hline $35-40$ & 17 & $22.7 \%$ & 11 & $14.7 \%$ & NS \\
\hline$>40$ & 9 & $12.0 \%$ & 7 & $9.3 \%$ & NS \\
\hline Total & 75 & $100 \%$ & 75 & $100^{\wedge} \%$ & -- \\
\hline \multicolumn{6}{|c|}{ Waist circumference of studied groups } \\
\hline Men>102 & \multirow{2}{*}{53} & \multirow{2}{*}{$70.7 \%$} & \multirow{2}{*}{46} & \multirow{2}{*}{$61.3 \%$} & \multirow{2}{*}{ NS } \\
\hline Women $>88$ & & & & & \\
\hline
\end{tabular}

NS= not significant.

Table (4): Metabolic syndrome in the studied groups.

\begin{tabular}{||l|c|c|c|c||}
\hline \multirow{2}{*}{\multicolumn{1}{|c|}{ Patients }} & \multirow{2}{*}{ Total } & \multicolumn{2}{|c|}{ Metabolic syndrome } & \multirow{2}{*}{ p-value } \\
\cline { 3 - 4 } & & No. & $\%$ & \\
\hline Diabetes & 75 & 35 & $46.7 \%$ & \multirow{2}{*}{0.002} \\
\hline Non-diabetics & 75 & 17 & $22.7 \%$ & \\
\hline
\end{tabular}

Table (5): Lipid profile in the studied groups.

\begin{tabular}{|c|c|c|c|c|c|c|}
\hline \multirow{2}{*}{ Lipid } & \multirow{2}{*}{ Target } & \multicolumn{2}{|c|}{ Diabetes $(n=75)$} & \multicolumn{2}{|c|}{ Non-diabetes $(n=75)$} & \multirow{2}{*}{ p-value } \\
\hline & & No. & $\%$ & No. & $\%$ & \\
\hline$\overline{\mathrm{TC}(\mathrm{mmol} / \mathrm{L})}$ & $>5.17$ & 15 & 20.0 & 12 & 16.0 & $\overline{\mathrm{NS}}$ \\
\hline $\mathrm{LDL}(\mathrm{mmol} / \mathrm{L})$ & $>2.6$ & 14 & 18.7 & 12 & 16.0 & NS \\
\hline HDL (mmol/L) & $\begin{array}{l}\text { men }<1.15 \\
\text { women }<1.4\end{array}$ & 10 & 13.3 & 14 & 18.7 & NS \\
\hline TG $(\mathrm{mmol} / \mathrm{L})$ & $>1.7$ & 16 & 21.3 & 14 & 18.7 & NS \\
\hline Atherogenic index & $>5$ & 30 & 40.0 & 28 & 37.3 & NS \\
\hline
\end{tabular}

NS $=$ Not significant 
Table (6): Angiographic data of the studied groups.

\begin{tabular}{|l|c|c|c|c|c||}
\hline \multirow{2}{*}{ Extent of Coronary disease } & \multicolumn{2}{|c|}{ Diabetes $(\mathrm{n}=75)$} & \multicolumn{2}{c|}{ Non-diabetes $(\mathrm{n}=75)$} & \multirow{2}{*}{ p-value } \\
\cline { 2 - 5 } & No. & $\%$ & No. & $\%$ & \\
\hline No significant lesion & 9 & 12.0 & 32 & 42.7 & $<0.001$ \\
\hline Single vessel & 14 & 18.7 & 17 & 22.7 & NS \\
\hline Two vessel disease & 27 & 36 & 10 & 13.3 & 0.05 \\
\hline Three vessel disease & 25 & 58.7 & 16 & 21.3 & $<0.001$ \\
\hline
\end{tabular}

NS = Not significant

Table (7): Characteristics of coronary angiography.

\begin{tabular}{||l|c|c|c|c||}
\hline \multirow{2}{*}{ Patients } & \multirow{2}{*}{ Total } & \multicolumn{2}{|c|}{ Diffuse vessels disease } & \multirow{2}{*}{ p-value } \\
\cline { 3 - 4 } & & No. & $\%$ & \\
\hline \hline Diabetes & 75 & 19 & 25.3 & \multirow{2}{*}{0.0099} \\
\hline Non-diabetes & 75 & 8 & 10.7 & \\
\hline
\end{tabular}

Table (8): The culprit coronary artery of the studied groups.

\begin{tabular}{|l|c|c|c|c|c||}
\hline \multirow{2}{*}{ Coronary artery } & \multicolumn{2}{|c|}{ Diabetes $(\mathrm{n}=75)$} & \multicolumn{2}{c|}{ Non-diabetes $(\mathrm{n}=75)$} & \multirow{2}{*}{$\mathrm{p}$-value } \\
\cline { 2 - 6 } & No. & $\%$ & No. & $\%$ & \\
\hline LMS & 3 & 4.0 & 2 & 2.7 & $<0.001$ \\
\hline LAD & 55 & 73.3 & 32 & 42.7 & NS \\
\hline Cx & 39 & 52.0 & 19 & 25.3 & $<0.001$ \\
\hline RCA & 42 & 56.0 & 22 & 29.3 & NS \\
\hline
\end{tabular}

NS $=$ Not significant

\section{Discussion}

This study was carried out to assess the effect of Type 2 diabetes mellitus (T2DM) as a risk factor for coronary artery disease on coronary angiographic findings comparing it with non-diabetic patients. Like another study ${ }^{(2)}$, we found that diabetic patients usually possess multiple coronary risk factors as shown in the analysis of their baseline clinical characteristics which revealed that diabetic patients were older, (probably because T2DM more commonly occurs in older patients when compared with type one diabetes mellitus and in some it may be discovered lately from its actual onset) with a higher prevalence of hypertension and previous myocardial infarction. Their atherogenic index was not significantly higher than non-diabetics as in some other studies ${ }^{(18)}$; this may be due to the effect of using statin drugs in both groups.

These risk factors although were statistically not significant probably because of the small sample of the study which required to increase in further study, are potentiated by hyperglycemic state. This explains why diabetic patients are more likely to have coronary atherosclerotic disease when compared with non-diabetic patients. The metabolic syndrome was more in diabetics due to the occurrence of cluster of defining risk factors. On the basis of these differences, a worse angiographic outcome in this group of patients could be expected. The angiographic findings in this study revealed that nonsignificant coronary lesions were more common in non-diabetic patients $(42 \%)$. This finding probably raises the importance of proper and careful selection of non-diabetic patients for coronary angiography and they should undergo non-invasive procedure like tread mill stress test before doing angiography.

On the other hand, the presence of diabetes in a patient suspected to have CHD may be 
strong indication for coronary angiography for confirmation of the disease, determine the choice of therapy and assess the prognosis.

The angiographically significant atherosclerotic coronary lesion among patients with diabetes was more diffuse than non-diabetics, as found in another study ${ }^{(19)}$ which showed that diabetic patients were associated with more extensive and diffuse coronary atherosclerosis. ${ }^{(20)}$ In addition, the prevalence of multi-vessel disease was higher among diabetics similar to the other studies ${ }^{(21)}$.

The incidence of the left main stem lesion was higher in diabetics as in another study ${ }^{(22)}$.

These finding probably may explain why diabetic patients with $\mathrm{CHD}$ have worse prognosis with higher mortality rate than nondiabetic patients ${ }^{(7-11)}$.

There are many mechanisms that explain the higher incidence of stenosis and occlusion rate in diabetic patients. These mechanisms include:

1. Haemostatic abnormalities; that predispose them for increased risk of vascular thrombosis. Platelet aggregation is increased with enhanced synthesis of thromboxane $\mathrm{A}_{2}{ }^{(23)}$ and platelet activation (platelet factor 4 and B-thromboglobulin) can be elevated ${ }^{(24)}$.

2. A relative hypercoagulability state may be present in diabetic patients. Procoagulant factors include fibrinogen, factor $\mathrm{VII}$, and von Willebrand factor may be increased in diabetics while the synthesis of prostacyclin is reduced ${ }^{(25)}$. While fibrinolysis may be attenuated because of increases in plasminogen activator inhibitor type 1 and lower levels of urokinase-type plasminogen activator $^{(26)}$.

3. Functional abnormalities of the vascular endothelium; diabetic patients have some vascular endothelial dysfunction which may further enhance the tendency to vasospasm and coronary thrombosis as hyperglycemia causes endothelial dysfunction by decreasing the production of endotheliumderived relaxing factor $^{(27)}$, increasing oxidative stress by vascular protein glycation $^{(28)}$ and free radical formation ${ }^{(29)}$, and decreasing prostacyclin production ${ }^{(30)}$.
Moreover; lipoprotein abnormalities ${ }^{(31)}$ may impair endothelium- dependent relaxation ${ }^{(32)}$ and a greater growth factor stimulation occurs in diabetics ${ }^{(33)}$. These factors are likely to produce a prothrombotic state in patients with diabetes, and may account for more aggressive coronary artery lesion. All these mechanisms, the prothrombotic state, imbalance of fibrinolytic systems and endothelial dysfunction may contribute and explain the problem of coronary stenosis with poor angiographic outcome in patients with diabetes mellitus. In this study the incidence of previous myocardial infarction $\{23(30.7 \%)\}$ was more in diabetic patients when compared with non-diabetics $\{16$ $(21 \%)\}$ and this is probably due to the more advanced coronary artery disease in diabetic patients.

Over-weight and obesity are associated with insulin resistance and metabolic syndrome. However the presence of abdominal obesity is more highly correlated with metabolic syndrome than the elevated BMI. The clinical significance of insulin resistance is gaining prominence, and has been associated with several medical conditions such as polycystic ovarian syndrome and syndrome $X$. While insulin resistance may precede the onset of type 2 diabetes, its presence portends a heightened risk of occurrence of myocardial infarction $^{(34)}$ and stroke ${ }^{(35)}$. Indeed, the United Kingdom Prospective Diabetes Study (UKPDS) showed a reduction in macrovascular events by improving insulin resistance with Metformin in obese patients with type 2 diabetes. ${ }^{(36)}$ Although the precise mechanisms for the deleterious effects of insulin resistance remain uncertain, excessive free fatty acids is likely to be a major contributor. They reduce production of the nitric oxide and other vasodilatory substances mediated through reactive oxygen radicals ${ }^{(37)}$.

\section{Conclusion}

Two major clinical implications may derive from our findings.

${ }^{*}$ First: diabetes is often associated with other risk factors that predispose to coronary heart disease and may influence the outcome. 
* Second: diabetic patients will have a worse angiographic outcome. Diabetic patients with suspected CHD are strong indication for coronary angiography which provide the clinician valuable information regarding the confirmation of the presence or absence of coronary artery disease, the prognosis of the patients with $\mathrm{CHD}$ and it determines the choice of therapy whether drug therapy, coronary stenting or surgical by pass graft depending on the type and the number of the coronary arteries involvement.

\section{References}

1. Amos AF, McCarty DJ, Zimmet P. The rising global burden of diabetes and its complications: estimates and projections to the year 2010. Diabetic Medicine. 1997;17:S7-.[Abstract].

2. Irina K., Jolantap, Hanna B, Beatat T. et al. Disturbances of Glucose metabolism in Men Referred for Coronary Arteriography: Diabetic care. 2001; 24: 897-901. 3.

3. Kannel WB, McGee DL: Diabetes and cardiovascular risk factors in the Framingham Study. JAMA, 1978; 38: 4651.

4. Stamler J, Vaccaro O, Neaton JD et al. Diabetes, other risk factors, and 12-yr cardiovascular mortality for men screened in the Multiple Risk Factor Intervention Trial. Diabetes Care. 1993;16:434-444. [Abstract]

5. Uusitupa MI, Niskanen LK, Siitonen O, Voutilainen E, Pyorala K. 5-year incidence of atherosclerotic vascular disease in relation to general risk factors, insulin level, and abnormalities in lipoprotein composition in non-insulin-dependent diabetic and nondiabetic subjects. Circulation. 1990;82:27-36[Medline].

6. Kenneth J, Richrd W, Nesto R, Cohen $M$, Muller J. Impact of diabetes on longterm survival After Acute Myocardial Infarction:Comparability of risk with prior myocardial infarction: Diabetes Care, 2001 , 24:1422-1427.

7. Aronson D, Rayfield EJ, Chesebro JH: Mechanisms determining course and outcome of diabetic patients who have had acute myocardial infarction. Ann Intern Med 126:296-306, 1997

8. Miettinen $\mathrm{H}$, Lehto $\mathrm{S}$, Salomaa $\mathrm{V}$, Mahonen M, Niemela M, Haffner SM, et al $\mathrm{J}$ : Impact of diabetes on mortality after the first myocardial infarction. Diabetes Care 21:69-75, 1998.

9. Herlitz J, Malmberg K, Karlson BW, Ryden L, Hjalmarson A: Mortality and morbidity during a five-year follow-up of diabetics with myocardial infarction. Acta Med Scand 224:31-38, 1988.

10. Haffner SM, Lehto S, Rönnemaa $T$ et al. Mortality from coronary heart disease in subjects with type 2 diabetes and in nondiabetic subjects with and without prior myocardial infarction. $N$ Engl $\mathrm{J}$ Med. 1998;330:229-234. [Abstract].

11. Shpend E, Adnan K, Urgen P, Anne W. Diabetes mellitus and the clinical and angiographic outcome after coronary stent placement J Am Coll Cardiol, 1998; 32:1866-1873.

12. Malmberg .k. DIAGAMI (Diabetes Insulin Glucose Infusion in Acute MI) study group BMJ, 1997 ;314 : 1512 -15.

13. Alvin Power, Diabetes mellitus, Denis L.Casper et al: Harrisons Principles of internal medicine, $16^{\text {th }}$ ed. Philadelphia ; McGraw- Hill ; 2005 ;P (2153).

14. Hanlon $P$, Byers $M$, Walker $B$, Summerton $C$. Environmental and nutritional factor in disease. Nicholas A. Nicki R. Brian R. Davidsons principle and practice of medicine. $20^{\text {th }}$ ed London. Churichil livingstone. 2006 : $p$ 93-113.

15. Philip S. Gleen D. Diabetes Mellitus. Chales C. Robert C. Joseph L. Cecil Essentials of Medicine $7^{\text {th }}$. Philadelphia. Saunders . 2004: p 621-45.

16. Eugene B. Disorder of the cardiovascular system. Dennis L.Anthony S. Eugene Braunwald. Stephen L. Harrison's principles of internal medicine $16^{\text {th }}$ ed . McGraw-Hill 2006: p 1432.

17. Donald S. Grossman's Cardiac Catheterization, Angiography \& Intervention, 7th Edition New-York. Lippincott Williams \& Wilkins. 2006 p 463. 
18. Allen P; Frank D; Arthur Z; David R.; Deena $\mathrm{K}$ et al .Morphologic Findings of Coronary Atherosclerotic Plaques in Diabetics postmortem Study JAMA, 2004; 24:1266.

19. Dortimer AC, Shenoy PN, Shiroff RA et al. Diffuse coronary artery disease in diabetic patients: fact or fiction? Circulation. 1978;57:133-136. [Medline].

20. Vlietstra RE, Kronmal RA, Frye RL et al. Factors affecting the extent and severity of coronary artery disease in patients enrolled in the Coronary Artery Surgery Study. Atherosclerosis. 1982;2:208-215.

21. Mak KH, Moliterno DJ, Granger CB et al. Influence of diabetes mellitus on clinical outcome in the thrombolytic era of acute myocardial infarction. J Am Coll Cardiol. 1997;30:171-179.[Abstract].

22. Ferranini E, Vichi S, Natali A, Severi S: Cardiac disease in diabetic patients. J Cardiovasc Pharmacol 28(Suppl. 4):S16S22, 1996.

23. Davi G, Catalano I, Averna M, et al. Thromboxane biosynthesis and platelet function in type II diabetes mellitus. $N$ Engl J Med. 1990;322:1769-1774[Abstract]

24. Ostermann $\mathrm{H}$, Van de Loo J. Factors of the hemostatic system in diabetic patients. A survey of controlled studies. Haemostasis. 1986;16:386-416[Medline]

25. Carmassi F, Morale M, Puccetti R, et al. Coagulation and fibrinolytic system impairment in insulin dependent diabetes mellitus. Thromb Res. 1992;67:643654[CrossRef][Medline]

26. Schneider DJ, Nordt TK, Sobel BE. Attenuated fibrinolysis and accelerated atherogenesis in type II diabetic patients. Diabetes. 1993;42:1-7[Abstract]

27. Johnstone MT, Creager SJ, Scales KM, Cusco JA, Lee BK, Creager MA. Impaired endothelium-dependent vasodilation in patients with insulin-dependent diabetes mellitus. Circulation. 1993;88:2510-2516 [Medline]

28. Sowers JR, Epstein M. Diabetes mellitus and hypertension: an update. Hypertension. 1995;26:896-979
29. Tesfamariam B. Free radicals in diabetic endothelial cell dysfunction. Free Radic Biol Med.1994;16:383-391[CrossRef] [Medline]

30. Umeda F, Inoguchi T, Nawata H. Reduced stimulatory activity on prostacyclin production by cultured endothelial cells in serum from aged and diabetic patients. Atherosclerosis. 1989; 75: 61-66 [CrossRef] [Medline]

31. Betteridge DJ. Diabetic dyslipidemia. Am J Med.1994;96:25S-31S[CrossRef][Medline]

32. Creager MA, Cooke JP, Mendelsohn M. Impaired vasodilation of forearm resistance vessels in hypercholesterolemic humans. J Clin Invest. 1990;86:228-234 [Medline]

33. Sobel BE, Woodcock-Mitchell J, Schneider DJ et al. Increased plasminogen activator inhibitor type 1 in coronary artery atherectomy specimens from type 2 diabetic compared with nondiabetic patients: a potential factor predisposing to thrombosis and its persistence. Circulation. 1998;97:2213-2221.[Medline]

34. Crall F, Roberts W. The extramural and intramural coronary arteries in juvenile diabetes mellitus. Am J Med. 1978;64:221230. [Medline]

35. Folsom AR, Rasmussen ML, Chambless LE et al. Prospective associations of fasting insulin, body fat distribution, and diabetes with risk of ischemic stroke. The Atherosclerosis Risk in Communities (ARIC) Study Investigators. Diabetes Care. 1999;22:1077-1083.[Abstract].

36. United Kingdom Prospective Diabetes Study Group. Effect of intensive bloodglucose control with metformin on complications in overweight patients with type 2 diabetes (UKPDS 34). Lancet. 1998;352:854-865. [CrossRef] [ISI] [Medline]

37. Inoguchi $\mathrm{T}$, Li $\mathrm{P}$, Umeda $\mathrm{F}$ et al. High glucose level and free fatty acid stimulate reactive oxygen species production through protein kinase C--dependent activation of $\mathrm{NAD}(\mathrm{P}) \mathrm{H}$ oxidase in cultured vascular cells. Diabetes.2000; 49: 1939_ 1945. [Abstract]. 